\title{
THE INFLUENCE OF SERVICE QUALITY TO CUSTOMER LOYALTY THROUGH CUSTOMER SATISFACTION AND BRAND IMAGE
}

\author{
Mohammad Rifai Afif, Dewi Tamara, Yasin Irwanuddin, Hermawan Pramunaryo \\ Binus Business School, Binus University Jakarta, Indonesia \\ Email: rifaiafif71@gmail.com,dtamara@binu.edu,yasin.irwanuddin@binus.ac.id, \\ hermawan.pramunaryo@binus.ac.id
}

\begin{abstract}
This study shows whether service quality affects customer loyalty, brand image, and satisfaction as intervening variables. The service quality is very important to understand the satisfaction of customer to company's product and services. The good and effective service quality is a combination of effective marketing strategy on retaining the customer and attract new customers. The customer loyalty in construction company is not easy to achieve due to special and customed expertise needed by each customer. The brand image in construction industry is not easy to achieve as in retail industry. The researcher used the quantitative method using survey or questionnaires. The researcher dispatched 300 surveys, but the returned is only 193, where the sample was the customers of PT Wijaya Karya Beton, Tbk. This paper utilizes Pearson's correlation and multiple linear regressions. The researcher also used hierarchical regression to assess the role of intervening. Indeed, the research result shows a significant relationship among purposed variables.
\end{abstract}

Keywords: service quality; customer loyalty; brand image; customer satisfaction

Received: 2021-10-22; Accepted: 2021-11-05; Published: 2021-11-20

\section{Introduction}

The service quality can create customer satisfaction. Good and effective service quality is a combination of marketing strategies that positively influence customer satisfaction and loyalty. The Increase in customer satisfaction causes a close relationship between the company and their customer, a good repurchase rate, customer loyalty, and a positive brand image. It means that good service quality is the driving factor for customer satisfaction and product consumption in forming customer loyalty. The company should grow and develop in a mid of intense commercial competition. The companies must provide a satisfactory service both to potential and existing customers (Kristia Ningsih, 2010). The need for good service quality is essential for the company's sustainability. The Comparison between the desires and what customers get will gain satisfaction. Then, the construction industry is complex, and meeting customer expectations is a challenge for organizations. There are two parts to the construction industry. First, construction includes the physical consequences on the construction

\begin{tabular}{ll}
\hline How to cite: & Afif, M, R., Tamara, D., Irwanuddin,Y., Pramunaryo, H., (2021) The Influence of Service Quality \\
& To Customer Loyalty Through Customer Satisfaction And Brand Image Syntax Idea, 3(11), https: \\
& doi.org/10.36418/syntax-idea.v3i11.1570 \\
E-ISSN: & 2684-883X \\
Published by: & Ridwan Institute
\end{tabular}


process and correlated parties such as buildings and civil workers. Second, the contractor or the party that holds a construction also includes services provided in establishing those two objects (United Nations, 2015).

The customers in the construction industry can be defined as project owners and people who need to build facilities. In short, a customer is someone who buys a product or service (Fatihudin \& Firmansyah, 2019) describes that a "client" is an entity that combines the interests of construction service buyers, potential users, and other interest groups. In this research, the customer is considered the owner or general contractor from an outsourcing perspective. It is different from "the customer" in general, including products, services, and businesses. Various factors can affect customer satisfaction in the construction industry. Those are competitive fees, timeliness, product quality, product and work safety, and the last is customer service quality (Budianto, 2012). That item is simple, and everyone can consider it objectively. However, service quality is hard to measure objectively because the determinants are unknown. It can result in a lack of clarity for business owners in providing services that meet customer expectations. Besides, that factor also can cause customers dissatisfaction. Then, it can significantly impact the customer's intention or the repetition to use or consume the product in the future.

PT Wijaya Karya Beton, Tbk is a business engaged in the precast concrete industry to fulfil the infrastructure project's needs. This company produces precast products such as electric poles, piles, retaining walls, Beam Bridge, waterways, and other precast products. PT Wijaya Karya Beton, Tbk also has private, state-owned, and government construction service sectors. Therefore, as a company that already has a pretty good brand image in concrete products. The researcher examines the service quality affects customer satisfaction, brand image, and customer loyalty for the products of WIKA Beton. It is also the measurement of the service quality of PT WIKA Beton that has never been done. According to (Semil, 2018) has done research about modelling service quality in small and medium construction projects in Thailand. They structured the equation using four dimension of service quality such as reliability, responsiveness, assurance, and tangibility. They found that customer satisfaction mediated the causal relationship between behavioral intention and service quality.

This research contributes to body of knowledge in several ways. First, the research of service quality in construction industry is rarely done. Second, the indicators of service quality are based on National Standard of Construction company. Third, the relation of among service quality, customer satisfaction and customer loyalty is explored and describe in this research.

\section{Research Methods}

1. Research Framework and Hypotheses

This study focuses on the Service Quality effect on Brand Image and Customer Satisfaction then its effect on Customer Loyalty. Service Quality (X) was used as the independent object variable. While, the object of research became the mediating 
variable, namely Customer Satisfaction and brand image, and for the dependent variable, namely Customer Loyalty. This study used quantitative method with survey approach. The period of research is six months from January to July in 2020.

From the description above, we define the research model:

$\mathrm{H} 2$

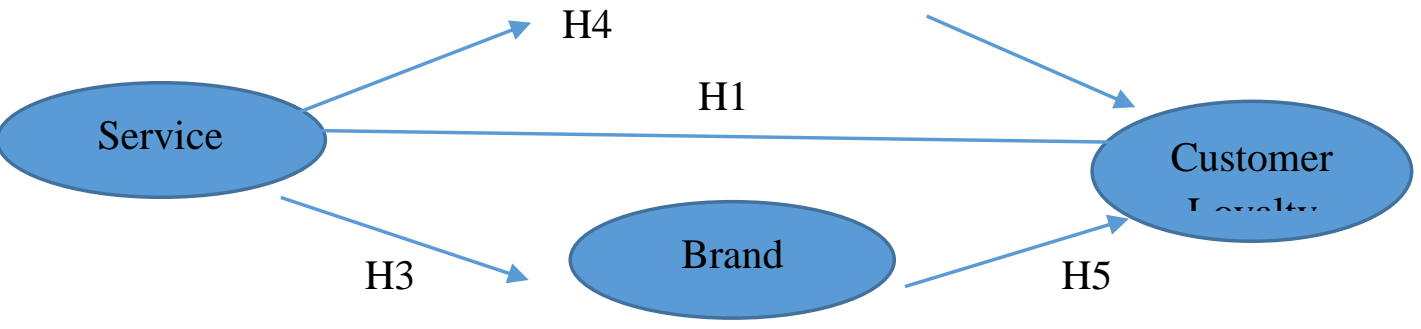

The following proposed hypotheses are:

H1: Service quality has a significant and positive effect on customer loyalty.

$\mathrm{H} 2$ : Service quality has a positive and significant effect on customer loyalty by intervening through customer satisfaction.

The population consisted of several individuals who had the same character, and they were determined as the research object so it would produce a conclusion (Sugiyono, 2014). The population used in this study was 193 customers of PT Wijaya Karya Beton, Tbk. This study used the purposive sampling method to determine the sample. Then the selected criteria were customers who purchased WIKA Beton products in 2020 and 2021.

\section{Results and Discussions}

The investigative variable measurement items were calculated and adjusted to accommodate the research context. Then, the measurement method uses A Likert Scale measurement with 5 points ranging from 1 "strongly disagree" to 5 "strongly agree". In this study, the researcher used five service quality indicators from Parasuraman et al (1988); three brand image indicators from (Lien et al., 2015), four customer satisfaction indicators by (Orel \& Kara, 2014), (Shpëtim, 2012) and three customer loyalty indicator by (Orel \& Kara, 2014). Qualitative analysis was used as Data analysis in this study. It also assisted with SPSS software.

The use of a validity test aims to measure the validity level of a questionnaire. A valid questionnaire is obtained if the questionnaire questions can describe measurable things in the questionnaire (Lastiawan, 2017). The validity test compares the calculated r-value from the output (the changed number of correlation elements) with the value in the $r$ table. If the result of the $r$ count is more significant than the $r$ table, the questionnaire is declared valid but vice versa. SPSS for this validity test is carried out using the Bivariate Pearson correlation analysis menu (Pearson's Product Moment). The results show that it is valid for all questions to be tested with results $<0.1850$ ( $\mathrm{r}$ table). A reliability test is used to check the reliability of the tools used data over time (Imam 
Ghozali, 2006). This test is carried out using the Cronbach's Alpha analysis technique menu. The measurement item is said to be reliable if the Cronbach's Alpha value is > 0.60. The reliability test results for each reliability variable followed the Cronbach's Alpha criteria, but no variable was less than 0.60 .

Table 1

Reliability Static

\begin{tabular}{lccl}
\hline \multicolumn{1}{c}{ Variable } & $\begin{array}{c}\text { Cronbach's } \\
\text { Alpha }\end{array}$ & N of Item & Conclusion \\
\hline Service Quality & .953 & 19 & Reliable* \\
Customer Satisfaction & .811 & 4 & Reliable* \\
Customer Loyalty & .905 & 3 & Reliable* \\
Brand Image & .883 & 3 & Reliable* \\
\hline
\end{tabular}

*. If the Cronbach's Alpha $>0.600=$ Sufficient Reliability

Table 1 shows that service quality, satisfaction, loyalty, and brand image were reliable variables.

The normality test was conducted to see whether the independent and dependent variables were normally or not normally distributed in the regression model (Suwandi, 2013). The normality test was carried out using the one-sample Kolmogorov Smirnov test. That is, the data is normally distributed if the significance value is greater than 0.05 . The SPSS output shows a significance value of $0.200>0.05$. It informs that the data were normally distributed.

The multicollinearity test is used to determine whether the regression model detects a correlation between independent variables (I Ghozali, 2005). The basis for making decisions in this multicollinearity test is whether the tolerance is $>0.10$ and the VIF value is $<10.00$. From the SPSS output, it can be concluded that the data is not multicollinear because the tolerance is greater than 0.1 and the VIF value is less than 10 . The variance test aims to check whether the regression model shows a variance that does not match the residuals from one observation to another (I Ghozali, 2005). It can be concluded that the data is asymptomatic because the results of the Glejser variance test with significance test criteria $>0.05$ the significance value obtained for all variables is $>0.05$.

Table 2

The correlation Analysis

\begin{tabular}{|c|c|c|c|c|c|c|}
\hline No & Description & & $\begin{array}{l}\text { Service } \\
\text { Quality }\end{array}$ & $\begin{array}{c}\text { Customer } \\
\text { Satisfaction }\end{array}$ & $\begin{array}{l}\text { Customer } \\
\text { Loyalty }\end{array}$ & $\begin{array}{l}\text { Brand } \\
\text { Image }\end{array}$ \\
\hline \multirow[t]{2}{*}{$\mathbf{1}$} & Service & Pearson & 1 & $0.852^{*}$ & $0.773 * *$ & $0.833^{* *}$ \\
\hline & Quality & $\begin{array}{c}\text { Correlation } \\
\text { Sig. (2- } \\
\text { tailed) }\end{array}$ & & 0.000 & 0.000 & 0.000 \\
\hline \multirow[t]{2}{*}{2} & Customer & Pearson & $0.852 *$ & 1 & $0.800 * *$ & $0.796 * *$ \\
\hline & Satisfaction & $\begin{array}{l}\text { Correlation } \\
\text { Sig. (2- }\end{array}$ & 0.000 & & 0.000 & 0.000 \\
\hline
\end{tabular}


The Influence of Service Quality to Customer Loyalty Through Customer Satisfaction and Brand Image

\begin{tabular}{ccccccc}
\hline No & Description & & $\begin{array}{c}\text { Service } \\
\text { Quality }\end{array}$ & $\begin{array}{c}\text { Customer } \\
\text { Satisfaction }\end{array}$ & $\begin{array}{c}\text { Customer } \\
\text { Loyalty }\end{array}$ & $\begin{array}{c}\text { Brand } \\
\text { Image }\end{array}$ \\
\hline & & tailed) & & & \\
\hline $\mathbf{3}$ & Customer & Pearson & $0.773^{* *}$ & $0.800^{* *}$ & 1 & $0.750^{* *}$ \\
& Loyalty & Correlation & 0.000 & 0.000 & & 0.000 \\
& & Sig. (2- & & & & \\
\hline $\mathbf{4}$ & Bailed) & & & $0.750^{* *}$ & 1 \\
& Image & Pearson & $0.833^{* *}$ & $0.796^{* *}$ & 0.000 & \\
& Correlation & 0.000 & 0.000 & & \\
& & Sig. (2- & & & & \\
& & tailed)
\end{tabular}

*Significant correlation at the $\mathbf{0 . 0 5}$ level (2-tailed) **Significant correlation at the 0.01 level (2-tailed)

Table 2 explained there is a positive and significant relationship between service quality and overall customer satisfaction (significance value $.000<.001$; Pearson correlation .852) and between service quality and customer loyalty (significance value $.000<.001$; Pearson correlation .773), and between service quality and brand image (significance value $.000<.001$; Pearson correlation .833). Therefore, it means a close correlation between the quality of service and its value to its customers. Therefore, the statement on H1- H3 are accepted.

Table 2 also explained the positive and significant findings of the correlation in customer both in satisfaction and loyalty (significance value $.000<.001$; Pearson correlation .800) and between the overall brand image and customer loyalty (significance value $.000<.001$; Pearson correlation .750). It shows a very close positive relationship between brand image, customer satisfaction, and customer loyalty. Therefore, $\mathrm{H} 4$ and $\mathrm{H} 5$ are supported.

The regression equation explained the relationship between service qualities, loyalty, brand image, and satisfaction. Therefore, the results obtained are presented below:

Table 3

Regression Analysis

\begin{tabular}{llllll}
\hline & Path & $\mathrm{R}$ & $\mathrm{R}^{2}$ & Adj. $\mathrm{R}^{2}$ & Sig. Level \\
\hline I & SQ-CL & 0,773 & 0,597 & 0,595 & 0,000 \\
\hline II & SQ-CS & 0,852 & 0,726 & 0,724 & 0,000 \\
\hline III & SQ-BI & 0,833 & 0,694 & 0,693 & 0,000 \\
\hline IV & CS-CL & 0,800 & 0,639 & 0,638 & 0,000 \\
\hline V & BI-CL & 0,750 & 0,563 & 0,561 & 0,000 \\
\hline VI & SQ-CS-CL & 0,819 & 0,670 & 0,667 & 0,000 \\
\hline VII & SQ-BI-CL & 0,796 & 0,634 & 0,630 & 0,000
\end{tabular}

Note : $\mathrm{SQ}=$ Service Quality, $\mathrm{CL}=$ Customer Loyalty, $\mathrm{CS}=$ Customer Satisfaction, $\mathrm{BI}=$ Brand Image

Path I: The correlation between customer loyalty with service quality. 
Service quality produces a significant relation $(\mathrm{R}=.773$, Sig. $=.000)$ toward Customer Loyalty. The correlation shows that the Service Quality variable, as an independent variable, explains $59.7 \%\left(\mathrm{R}^{2}=.597\right)$ of the dependent variable, Customer Loyalty. It explains why there is a high correlation between service quality and customer loyalty.

Path II: The correlation between Customer Satisfaction toward Service Quality.

There is a significant relationship service quality $(\mathrm{R}=.852$, Sig. $=.000)$ toward Customer Satisfaction. This correlation explains that the independent variable is $72.6 \%$ $\left(\mathrm{R}^{2}=.726\right)$ toward the dependent variable, namely Customer Satisfaction. This model shows that there is a significant relationship on Customer Satisfaction toward Service Quality.

Path III: The connection on Service Quality toward Brand Image.

There is a significant relationship between variable Service quality $(R=.833$, Sig. $=.000)$ toward Brand Image variable. This correlation explains that the independent variable, namely Service Quality is $69.4 \%\left(\mathrm{R}^{2}=.694\right)$ of the dependent variable variance, namely Brand Image. The result explains the strong relationship on Service Quality toward Brand Image.

Path IV: The relationship on Customer Satisfaction toward Customer Loyalty.

There is a significant relationship between customer satisfaction quality $(\mathrm{R}=.800$, Sig.= .000) toward Customer Loyalty. This correlation defines that the independent variable, namely Customer Satisfaction has $63.9 \%\left(\mathrm{R}^{2}=.639\right)$ on dependent variable variance, namely Customer Loyalty. This model shows that there is a significant relationship on Customer Satisfaction toward Customer Loyalty.

Path V: The relationship on Brand Image toward Customer Loyalty.

Brand image has an important relationship with customer loyalty $(\mathrm{R}=.750$, Sig.= $.000)$. This correlation defines that the independent variable (Brand Image) shows $56.3 \%\left(\mathrm{R}^{2}=.563\right)$ toward the dependent variable, namely Customer Loyalty. It shows that a significant relationship on Brand Image toward Customer Loyalty.

Path VI: The Correlation on Customer Satisfaction, Service Quality and Customer Loyalty.

Service quality has an essential relationship toward customer satisfaction and also customer loyalty. This connection defines the independent variables, namely, service quality and also customer satisfaction. It also explains the variance of $67.0 \%\left(\mathrm{R}^{2}=\right.$ 0.670 ) of customer loyalty as a dependent variable. It indicates that service quality and customer satisfaction and loyalty are linked.

Path VII: The relationship on Service Quality, Brand Image, and Customer Loyalty. 
Service quality has important implications for brand image and customer loyalty. It shows the correlation of the independent variables, namely service quality and brand image. It also explains the dependent variable's variance (customer loyalty) of $63.4 \%$ $\left(\mathrm{R}^{2}=0.63\right)$. This model shows a significant correlation on service quality toward brand image and customer loyalty.

Table 4

Regression Model of Hypothesis

\begin{tabular}{lllll}
\hline & Path & Constant & Model & Sig. Level \\
\hline VI & SQ-CS-CL & $-2,220$ & CL=-2,220+0,079SQ+0,405CS & 0,000 \\
\hline VII & SQ-BI-CL & $-3,369$ & CL $=-3,369+0,114 S Q+0,423 B I$ & 0,000 \\
\hline
\end{tabular}

Note: $\mathrm{SQ}=$ Service Quality, $\mathrm{CL}=$ Customer Loyalty, $\mathrm{CS}=$ Customer Satisfaction, BI= Brand Image

Table 4 path VI shows the effect of Service Quality through Customer Satisfaction intervention on Customer Loyalty. Service Quality has a direct influence on Customer Loyalty of 0.334 or $33.4 \%$. In determining the Service Quality effect indirectly on Customer Loyalty, it used beta multiplication (Quality of Service with Customer Satisfaction) with a beta value (Customer Satisfaction toward Customer Loyalty), namely: $0.852 \times 0.515=0.438$. Then, the direct effect is 0.334 or $33.4 \%$, and the indirect effect is 0.438 or $43.8 \%$. It means that the indirect effect is greater than the direct effect. Therefore, it results that the service quality variable indirectly affects customer loyalty through customer satisfaction interventions. (HYPOTHESIS ACCEPTED).

Table 4 path VII shows the effect of Service Quality through Brand Image intervention on Customer Loyalty. Service Quality has a direct influence on Customer Loyalty of 0.483 or $43.8 \%$. In determining the influence of Service Quality indirectly on Customer Loyalty, using beta multiplication (Quality of Service with Brand Image) with a beta value (Brand Image toward Customer Loyalty), namely: 0.833 x $0.348=0.289$. It is also known that the direct effect is 0.483 or $48.3 \%$, and the indirect effect is 0.289 or $28.9 \%$. It means that the indirect effect is smaller than the direct effect. Therefore, it shows that the service quality variable indirectly influences customer loyalty on Brand Image intervention.

The result of service quality in this research is in line with the nature of construction industry. The repeat orders can be come from the repeat customers, and also from new customers. The customer relationship in construction industry is more intermittent comparing to other industries (Hadikusumo and Sunindijo, 2004).

\section{Conclusion}

The research results indicate the significant relationship between service quality, brand image, customer loyalty, and satisfaction. It is following various prior researches. Therefore, business actors should focus on strategies to achieve the highest level of customer loyalty. Then, that goals can be achieved by increasing customer perceptions 
Mohammad Rifai Afif, Dewi Tamara, Yasin Irwanuddin, Hermawan Pramunaryo

of service quality, customer satisfaction, and brand image. Companies must be wellmanaged the service quality. Then, there is a direct relationship between service quality and customer loyalty. It is also an indirect relationship between brand image and customer loyalty. Then, it is also in customer satisfaction toward customer loyalty. Customer satisfaction and brand image are intervening variables. However, customer loyalty will benefit companies' growth.

Future research is expected to explore the possibility of other intervening variables by assessing the variables and the relationship strength between variables. Researchers can use the structural equation to identify intervening factors and assess the strength of the impact of these intervening variables. 
The Influence of Service Quality to Customer Loyalty Through Customer Satisfaction and Brand Image

\section{BIBLIOGRAFI}

Budianto, A. (2012). Analisis Kepuasan Konsumen Dalam Produk Konstruksi (Studi Kasus Perumahan Bukit Permata Puri Di Kota Semarang). magister teknik sipil.Google Scholar

Fatihudin, D., \& Firmansyah, A. (2019). Pemasaran Jasa:(Strategi, Mengukur Kepuasan Dan Loyalitas Pelanggan). Deepublish. Google Scholar

Ghozali, I. (2005). Aplikasi Analisis Multivariate dengan Program SPSS (3rd ed.).

Ghozali, Imam. (2006). Aplikasi analisis multivariate dengan program SPSS. Badan Penerbit Universitas Diponegoro. Google Scholar

Kristia Ningsih, E. K. A. (2010). Pelayanan Satu Atap Sebagai Strategi Pelayanan Prima Di Era Otonomi Daerah (Studi Pada Kantor Pelayanan Perijinan Terpadu (KPPT) Kota Batu). University of Muhammadiyah Malang. Google Scholar

Lastiawan, A. F. (2017). Pengaruh Tempat Spa Massage Terhadap Prilaku Menyimpang Di Kalangan Remaja (Studi deskriptif di Jalan Astana Anyar Kota Bandung). FKIP UNPAS. Google Scholar

Lien, C.-H., Wen, M.-J., Huang, L.-C., \& Wu, K.-L. (2015). Online hotel booking: The effects of brand image, price, trust and value on purchase intentions. Asia Pacific Management Review, 20(4), 210-218. Google Scholar

Orel, F. D., \& Kara, A. (2014). Supermarket self-checkout service quality, customer satisfaction, and loyalty: Empirical evidence from an emerging market. Journal of Retailing and Consumer Services, 21(2), 118-129. Google Scholar

Semil, N. (2018). Pelayanan prima instansi pemerintah: kajian kritis pada sistem pelayanan publik di Indonesia. Prenada Media. Google Scholar

Shpëtim, C. (2012). Exploring the Relationships among Service Quality. Satisfaction, Trust and Store Loyalty among Retail Customers in Journal of Competitiveness, 4(4), 16-35. Google Scholar

Sugiyono. (2014). Metode Penelitian Pendidikan (Pendekatan Kuantitatif, Kualitatif dan $R \& D)$. Alfabeta. Google Scholar

Suwandi, A. P. (2013). Pengaruh kejelasan sasaran anggaran dan desentralisasi terhadap kinerja pemerintah daerah (Studi empiris pada SKPD Pemerintah Kota Padang). Jurnal Akuntansi, 1(2). Google Scholar

United Nations. (2015). Central Product Classification (CPC) Version 2.1, 4, March. 
Mohammad Rifai Afif, Dewi Tamara, Yasin Irwanuddin, Hermawan Pramunaryo

\section{Copyright holder:}

Mohammad Rifai Afif, Dewi Tamara, Yasin Irwanuddin, Hermawan Pramunaryo (2021)

\section{First publication right: \\ Syntax Idea}

This article is licensed under:

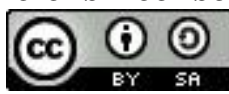

